Research Article

\title{
A Study to Assess the Knowledge of Adults regarding the Importance of Sanitary Latrine in Selected Rural Area at Bhopal
}

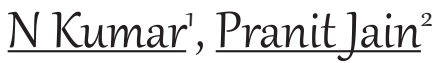 \\ ${ }^{1}$ Department of Nursing, Sarvepalli Radhakrishnan University, Bhopal, Madhya Pradesh, India. \\ ${ }^{2}$ Professor \& Principal, VIP College of Nursing, Bhopal, Madhya Pradesh, India.
}

DOI: https://doi.org/10.24321/2348.2133.201902

\section{I $\quad \mathbf{N} \quad \mathbf{F} \mathbf{O}$}

\section{Corresponding Author:}

Pranit Jain, VIP College of Nursing, Bhopal, Madhya Pradesh, India.

E-mail Id:

pranit.jain@yahoo.com

Orcid Id:

https://orcid.org/0000-0001-9727-8778

How to cite this article:

Kumar N, Jain P. A Study to Assess the Knowledge of Adults regarding the Importance of Sanitary Latrine in Selected Rural Area at Bhopal. Ind J Holist Nurs 2019; 10(1): 8-15.

Date of Submission: 2019-08-29

Date of Acceptance: 2019-10-07

\section{$\begin{array}{llllllll}\mathbf{A} & \mathbf{B} & \mathbf{S} & \mathbf{T} & \mathbf{R} & \mathbf{A} & \mathbf{C} & \mathbf{T}\end{array}$}

Background of the Study: According to (WHO, 1987) information, "the provision of sanitary facilities for the prevention and control of parasitic infection and this aim of controlling intestinal parasites through proper use of the necessary components of any for excreta disposal.

Objective: To assess the existing knowledge of adults regarding the importance of sanitary latrine. To assess the attitude of the adults regarding the importance of sanitary latrine. To correlate the knowledge and attitude of adults regarding the importance of sanitary latrine. To associate the knowledge and attitude of adults with selected demographic variables. To create awareness regarding the importance of sanitary latrine by developing a pamphlet to motivate and construct their own sanitary latrines.

Methods: A descriptive approach is selected for the study. The research design selected for the study was Non experimental descriptive study design which is used to assess the knowledge and attitude of adults regarding the use of sanitary latrine. The study was conducted in selected villages namely Deva mau, Shanti nager,Gopal kunj and Dodda basti village under Utrathia PHC Bhopal 120 rural adults who fulfil the inclusion criteria.

Conclusion: The findings of the study have been discussed with reference to the objectives, hypothesis and with the findings of other studies. The data is organized, analyzed and presented. The findings of the shows that majority of the adults $87(72.5 \%)$ had moderate adequate knowledge, $60(50 \%)$ of adults had moderately favourable attitude. This showed that knowledge and attitude of the adults are inadequate and health educations regarding importance of sanitary latrine are needed to improve the knowledge and attitude.

Keywords: Knowledge, Adults, Sanitary Latrine, Rural Area 


\section{Introduction}

The word "latrine" is derived from the Latin lavatrina, meaning bath. It is nowadays still commonly used in the term "pit latrine". The use of sanitary latrines or privies can be very effective in helping to control the disease, which can be spread by water, soil, insects, or dirty hands. While it is necessary to have a sanitary water and food supply, sufficient medical service, and adequate diet to stop the disease, the sanitary latrine breaks the disease cycle. ${ }^{1}$

Sanitation is the means of collecting and disposing of excreta and community liquid wastes in a hygienic way so as not to endanger the health of individual. Open defecation and unsafe excreta disposal continue to be widespread in rural India with major public health and economic consequences. Lack of sanitation and unhygienic practices facilitates the transmission of pathogens resulting in many potential diseases. Inadequate sanitation is associated with significant morbidity from diarrheal disease, soil-transmitted infection, trachoma etc. ${ }^{2}$

\section{Need for the Study}

According to (WHO, 1987) information, "the provision of sanitary facilities for Prevention and control of parasitic infection and this aim at controlling intestinal parasites through proper use of necessary components of any for excreta disposal.

Clean environment is the important and basic health need in many areas, the sanitary is the important need for health and those who are concerned important health need authorities which is minimized and controlling of intestinal parasites and those are the provision of sanitation facilities like providing sanitary facilities and proper water supply at all community levels. ${ }^{3}$

In many developing countries, there are no proper facilities of defecation of human excreta it is usually done in open field defecation, this the way of life in our India peoples. This type of Environmental hazards is very serious for health. "Swachh Bharat Mission" has launched by the prime mister of India aims to focus on sanitation through achieving universal sanitation coverage. ${ }^{4}$

In a daily life human being are develops so many wastes in different places like home cooking and solid waste, human waste like urine, faces, and works place like school college and hospitals are producing so may wastes. There is need to control all these type of waste for better health and environment for the next generation and provide the education at every level of community area because the peoples who are living in urban areas, they are live in close together and there are no many spaces to manage disposal of daily waste. ${ }^{5}$

\section{Problem Statement}

A study to assess the Knowledge of adults regarding the importance of Sanitary Latrine in Selected Rural Area at Bhopal (M.P).

\section{Objectives}

The objectives of this study were:

- To assess the existing knowledge of adults regarding the importance of sanitary latrine

- To assess the knowledge and attitude of adults with selected demographic variables.

- To find the association between pre-test knowledge scores of adults and selected demographic variables.

\section{Hypothesis}

- $\mathbf{H}_{1}$ : There will be a significant correlation between the knowledge and attitude of rural people regarding sanitary latrine.

- $\mathbf{H}_{2}$ : There will be a significant association between the knowledge and attitude of rural people regarding sanitary latrine with selected demographic variables.

\section{Methods}

It was used to assess the knowledge and attitude of adults regarding importance of sanitary latrine. The research design selected for the study was Non experimental descriptive study design which is used to assess the knowledge and attitude of adults regarding the use of sanitary latrine.

\section{Research Variables}

Dependent Variables: Level of knowledge and attitude of adults regarding importance of sanitary latrine.

Independent Variables: Demographic variables such as to age, sex, religion, type of family, education status, occupation, monthly income, area of defecation, uses of foot wears, hand washing, sources of information, history of communicable diseases.

\section{Setting of the Study}

The study was conducted in selected villages namely Deva mau, Shanti nager, Gopalkunj and Dodda basti village under Utrathia PHC Bhopal. The PHC covers 23 villages with the population of 16592 .

\section{Population}

The population of this study is rural adults residing under Deva mau, Shanti nager Gopal kunjand Dodda basti village.

\section{Sample and Sampling Technique}

In this study sample size is 120 rural adults who fulfil the inclusion criteria. The criteria for sample selection are mainly depicted under two headings which includes the inclusive and exclusive criteria. 


\section{Inclusion Criteria}

This study includes both male and female who:

- Are residing under Uthrathia PHC.

- Are the head of the family.

- Are willing to participate in the study.

\section{Exclusion Criteria}

This study will exclude who:

- $\quad$ Are having their own sanitary latrines.

\section{Sampling Technique}

A convenience sampling technique was used for the selection of samples. The samples were those available at the time of data collection and also who fulfil the inclusion criteria.

\section{Development and Description of Tool}

An instrument selected in a research should be as for as possible the vehicle that would best obtains data for drawing conclusions which are pertinent to the study.

A structured interview schedule was developed by the investigator in order to obtain exact and complete response from the adults. To assess the knowledge structured questionnaire was used and Likert"s scale was used to assess the attitude.

After an extensive review of literature and discussion with the experts the structured interview schedule consisting of 20 knowledge questions and 20 attitude questions were developed and planned

\section{Content Validity}

The prepared tool with the objectives was submitted to four Community nursing experts, one Community Medicine Experts and one Biostatistician. The tool got final shape after the incorporation of the modifications based on the opinions of the experts.

\section{Reliability of the Tool}

The structured questionnaire was administered to 30 adults of rural community. In order to establish reliability of the tool, the split half technique with the Spearman Brown's Prophecy formula was used and reliability co-efficient of the tool was calculated by using raw score formula i.e. $r$ $=2 r / 1+r$.

The calculated " $r$ " value was 0.85 for knowledge questionnaire and 0.76 for attitude scale. Hence the developed tool was found to be reliable.

\section{Pilot Study}

The function of the pilot study is to obtain information for the approving the project or for assessing its feasibility. For the pilot study the investigator selected Utrathiya village,
Bhopal.

After obtaining permission from the Lady Medical officer of Utrathiya, primary Health Centre, the investigator conducted a pilot study in Deva mau village, with 30 samples by using non-probability convenient sampling technique

The pilot study was conducted for a period of one week. Through this pilot study, it was found out that majority of the adults $27(75 \%)$ have moderate knowledge, most of them $21(58.33 \%)$ have favourable attitude regarding the importance of sanitary latrine

Data collection is the gathering of information needed to address research problem. Formal written permission was obtained from Male medical officer in Primary Health Centre, Utrathiya, Bhopal for conducting the main study. The structured interview method was adopted for the data collection and was carried out for a period of four week from 1st April. to 31 April. 2018

\section{Plan for Data Analysis}

The obtained data was planned to analyse on the basis of the objectives of the study using the descriptive and inferential statistics.

\section{Descriptive Statistics}

- $\quad$ Frequency and percentage distribution were used to analyse the demographic variables.

- Frequency and percentage distribution of the level of knowledge and attitude of adults on importance of sanitary latrine.

- Mean, standard deviation, mean difference were used to determine the knowledge and attitude of adults on importance of sanitary latrine.

\section{Inferential Statistics}

- Karl Pearson's correlation co-efficient test was used to find out the correlation between the level of knowledge and attitude of adults.

- $\quad$ Chi square test was used to determine the association between knowledge and attitude with demographic variables.

\section{Ethical Consideration}

Formal permission was obtained from the setting before the conduction of the study. Informed consent was obtained from the samples before conducting the study explaining about the purpose of the study and assuring confidentiality of collected data. There were no ethical issues arising during the course of study.

\section{Result}

\section{The result is divided in following section:}

- Section A: Description of demographic characteristics of adults. 
- $\quad$ Section B: Assessment of the level of knowledge of adults regarding importance of sanitary latrine.

- Section C: Assessment of the level of attitude of adults regarding importance of sanitary latrine.

- Section D: Correlation between knowledge and attitude of the adults regarding importance of sanitary latrine.

Table I(I).Frequency and percentage distribution of adults according to age, sex, religion and type of family

\begin{tabular}{|c|c|c|c|c|}
\hline $\begin{array}{l}\text { S. } \\
\text { No. }\end{array}$ & $\begin{array}{c}\text { Demographic } \\
\text { variables }\end{array}$ & Characters & $\begin{array}{l}\text { Freq- } \\
\text { uency }\end{array}$ & $\begin{array}{c}\text { Percentage } \\
\text { (\%) }\end{array}$ \\
\hline \multirow{5}{*}{1.} & \multirow{5}{*}{ Age } & Below 25 & - & - \\
\hline & & $26-29$ & 27 & 7.5 \\
\hline & & $30-35$ & 84 & 23.3 \\
\hline & & $36-39$ & 165 & 45.8 \\
\hline & & $\begin{array}{c}40 \& \\
\text { above }\end{array}$ & 84 & 23.3 \\
\hline \multirow{2}{*}{2.} & \multirow{2}{*}{ Sex } & Male & 339 & 94.2 \\
\hline & & Female & 21 & 5.8 \\
\hline \multirow{4}{*}{3.} & \multirow{4}{*}{ Religion } & Hindu & 336 & 93.3 \\
\hline & & Muslim & 24 & 6.7 \\
\hline & & Christian & - & - \\
\hline & & Others & - & - \\
\hline \multirow{2}{*}{4.} & \multirow{2}{*}{$\begin{array}{l}\text { Type of } \\
\text { family }\end{array}$} & Nuclear & 72 & 20.0 \\
\hline & & Joint & 288 & 80.0 \\
\hline
\end{tabular}

\section{Section A: Demographic Variables of Adults}

The above table represents the frequency and percentage distribution of adults according to age, sex, religion, type of family, education status, occupation, monthly income, area of defecation, uses of foot wears, hand washing, sources of information, and history of communicable diseases.

- With regards to age, majority of subjects 165 (45.8\%) were between $36-39$ years, 84 (23.3) were between the age of $30-35$ years and $40 \&$ above, 27 (7.5\%) were between $26-29$ years.

- $\quad$ Gender majority 339 (94.2\%) was male and 21(5.8\%) was female.

- $\quad$ Regarding religion, majority of the subjects 336 (93.3\%) were Hindus, 24 (6.7\%) were Muslims.

- According to the type of family, 288 (80\%) belongs to joint family, \& 72 (20\%) belongs to nuclear family.

- $\quad$ Based on their educational status, majority 222 (61.7\%) had no formal education, $99(27.5 \%)$ had primary, 36 $(10 \%)$ had secondary education and only $3(0.8 \%)$ had higher secondary.
- $\quad$ Considering the occupation, majority 150 (41.7\%) were coolie/ labourer, 141 (39.2\%) were business/ selfemployed, 45 (12.5\%) were housewife/ unemployed, $24(6.7 \%)$ were private employed.

- According to family income it reveals that 336 (93.3\%) earns below 4000/-, 24(6.7\%) earns between Rs. 40016000/-.

- Regarding area of defecation, 348 (96.7\%) used open field, 12 (3.3\%) used public latrine.

Table I(2).Frequency and percentage distribution of adults according to educational status, occupation, family income and area of defecation

\begin{tabular}{|c|c|c|c|c|}
\hline $\begin{array}{l}\text { S. } \\
\text { No. }\end{array}$ & $\begin{array}{c}\text { Demographic } \\
\text { Variables }\end{array}$ & Characters & $\begin{array}{l}\text { Freq- } \\
\text { uency }\end{array}$ & $\begin{array}{c}\text { Percentage } \\
(\%)\end{array}$ \\
\hline \multirow{5}{*}{1.} & \multirow{5}{*}{$\begin{array}{c}\text { Educational } \\
\text { status }\end{array}$} & $\begin{array}{l}\text { No formal } \\
\text { education }\end{array}$ & 222 & 61.7 \\
\hline & & $\begin{array}{l}\text { Primary } \\
\text { school }\end{array}$ & 99 & 27.5 \\
\hline & & $\begin{array}{c}\text { Secondary } \\
\text { school }\end{array}$ & 36 & 10.0 \\
\hline & & $\begin{array}{c}\text { Higher } \\
\text { secondary }\end{array}$ & 3 & 0.8 \\
\hline & & $\begin{array}{c}\text { Graduate \& } \\
\text { above }\end{array}$ & - & - \\
\hline \multirow{5}{*}{2.} & \multirow{5}{*}{ Occupation } & $\begin{array}{c}\text { Housewife/ } \\
\text { unem- } \\
\text { ployed }\end{array}$ & 45 & 12.5 \\
\hline & & $\begin{array}{l}\text { Coolie / } \\
\text { labourer }\end{array}$ & 150 & 41.7 \\
\hline & & $\begin{array}{c}\text { Pvt. } \\
\text { Employee }\end{array}$ & 24 & 6.7 \\
\hline & & $\begin{array}{c}\text { Govt. } \\
\text { employee }\end{array}$ & - & - \\
\hline & & $\begin{array}{l}\text { Business/ } \\
\text { self } \\
\text { employed }\end{array}$ & 141 & 39.2 \\
\hline \multirow{4}{*}{3.} & \multirow{4}{*}{$\begin{array}{c}\text { Family } \\
\text { income (Rs./ } \\
\text { month) }\end{array}$} & Below 4000 & 336 & 93.3 \\
\hline & & 4001-6000 & 24 & 6.7 \\
\hline & & $6001-8000$ & - & - \\
\hline & & $\begin{array}{c}8001 \& \\
\text { above }\end{array}$ & - & - \\
\hline \multirow[b]{2}{*}{4.} & \multirow{2}{*}{$\begin{array}{c}\text { Area of } \\
\text { defecation }\end{array}$} & Open field & 348 & 96.7 \\
\hline & & $\begin{array}{l}\text { Public } \\
\text { Latrine }\end{array}$ & 12 & 3.3 \\
\hline
\end{tabular}

- Considering the use of foot wears while going for defecation, 103 (85.8\%) wear foot wears and 17 (14.2\%) does not used foot wears. 
- $\quad$ Regarding hand washing, 60 (50\%) washes their hand with water and 60 (50\%) washes their hand with soap and water.

- According to the source of information it reveals that of $111(92.5 \%)$ from mass media, 8 (6.7\%) from friends/ relatives, $1(0.8 \%)$ from health personnel.

Table I(3).Frequency and percentage distribution of adults according to uses of foot wear, hand washing, source of information and history of communicable diseases

\begin{tabular}{|c|c|c|c|c|}
\hline $\begin{array}{l}\text { S. } \\
\text { No. }\end{array}$ & $\begin{array}{c}\text { Demographic } \\
\text { variables }\end{array}$ & Characters & $\begin{array}{l}\text { Freq- } \\
\text { uency }\end{array}$ & $\begin{array}{c}\text { Percentage } \\
(\%)\end{array}$ \\
\hline \multirow{2}{*}{1.} & \multirow{2}{*}{$\begin{array}{c}\text { Uses of foot } \\
\text { wear }\end{array}$} & Yes & 103 & 85.8 \\
\hline & & No & 17 & 14.2 \\
\hline \multirow[b]{2}{*}{2.} & \multirow{2}{*}{$\begin{array}{c}\text { Hand } \\
\text { washing }\end{array}$} & $\begin{array}{c}\text { Washing } \\
\text { with water }\end{array}$ & 60 & 50.0 \\
\hline & & $\begin{array}{c}\text { Washing } \\
\text { with soap } \\
\text { water }\end{array}$ & 60 & 50.0 \\
\hline \multirow{4}{*}{3.} & \multirow{4}{*}{$\begin{array}{l}\text { Source of } \\
\text { information }\end{array}$} & $\begin{array}{l}\text { Mass } \\
\text { media }\end{array}$ & 111 & 92.5 \\
\hline & & $\begin{array}{c}\text { Health } \\
\text { personnel }\end{array}$ & 1 & 0.8 \\
\hline & & $\begin{array}{l}\text { Friends \& } \\
\text { relatives }\end{array}$ & 8 & 6.7 \\
\hline & & $\begin{array}{l}\text { Other } \\
\text { sources }\end{array}$ & - & - \\
\hline \multirow[b]{2}{*}{4.} & \multirow{2}{*}{$\begin{array}{l}\text { History } \\
\text { of comm- } \\
\text { unicable } \\
\text { disease }\end{array}$} & Yes & 15 & 12.5 \\
\hline & & No & 105 & 87.5 \\
\hline
\end{tabular}

Considering the history of communicable disease 105 $(87.5 \%)$ family does not have communicable disease and 15 (12.5\%) family have communicable diseases.

\section{Section B: Assessment of Knowledge}

Table 2(I).Frequency and percentage distribution of adults according to level of knowledge regarding importance of sanitary latrine

\begin{tabular}{|c|c|c|c|}
\hline S. No. & Level of knowledge & Number & $\%$ \\
\hline 1. & Inadequate knowledge & 28 & 23.3 \\
\hline 2. & $\begin{array}{c}\text { Moderately adequate } \\
\text { knowledge }\end{array}$ & 87 & 72.5 \\
\hline 3. & Adequate knowledge & 5 & 4.2 \\
\hline 4. & Over all & 120 & 100.0 \\
\hline
\end{tabular}

Above table shows the level of knowledge of adults in which
$87(72.5 \%)$ were having moderately adequate knowledge, $28(23.3 \%)$ were found to have inadequate knowledge, and $5(4.2 \%)$ of them had adequate knowledge regarding importance of sanitary latrine.

It shows that majority of the adults were having moderate and inadequate knowledge and few of them had adequate knowledge.

Table 3(I).Frequency and percentage distribution of adults according to level of attitude regarding importance of sanitary latrine

\begin{tabular}{|c|c|c|c|}
\hline S. No. & Level of Attitude & Number & $\%$ \\
\hline 1. & Unfavourable attitude & 45 & 37.5 \\
\hline 2. & $\begin{array}{c}\text { Moderately favourable } \\
\text { attitude }\end{array}$ & 60 & 50.0 \\
\hline 3. & Favourable attitude & 15 & 12.5 \\
\hline 4. & Over all & 120 & 100.0 \\
\hline
\end{tabular}

\section{Section C: Assessment of Attitude}

Above table depict that $60(50.0 \%)$ adults were having moderately favorable attitude, $45(37.5 \%)$ were having unfavorable attitude and $15(12.5 \%)$ were having favorable attitude regarding importance of Sanitary latrine.

Table 4(I).Correlation between knowledge and attitude regarding importance of sanitary latrine among adults

\begin{tabular}{|c|c|c|}
\hline \multirow{2}{*}{ Variable } & \multicolumn{2}{|c|}{$\mathrm{n}=120$} \\
\cline { 2 - 3 } & $\mathbf{R}$ & $\mathbf{p}$-value \\
\hline Knowledge & $0.478^{*}$ & $\mathrm{P}<0.01$ \\
\hline
\end{tabular}

\section{Section D: Assessment of Correlation}

The above table represents that the correlation coefficient computed between the overall Mean knowledge and overall Mean attitude of adults as $r=0.478^{*}$ which was found to be significant at $p<0.01$ level hence it suggest that there is a linear (positive) correlation between knowledge and attitude. It indicates that increase in knowledge results in increase in attitude of adults regarding importance of sanitary latrine.

\section{Section E: Association of Knowledge and Attitude with Demographic Variables of Adults}

chi-square analysis to determine the association of knowledge with selected demographic variables such as age, sex, religion, type of family, education status, occupation. In relation to the variables, age $(\chi 2=1.344, d f=3)$, sex $(\chi 2=$ $0.350, d f=1)$, religion $(\chi 2=0.422, d f=1)$, type of family 
$(\chi 2=0.560, d f=1)$, educational status $(\chi 2=2.287, d f=3)$, occupation $(\chi 2=0.954, \mathrm{df}=3)$ does not show any association with level of knowledge.

Chi-square analysis to determine the association of knowledge with selected demographic variables such as family income, area of defecation, uses of foot wears, hand washing, sources of information \& history of communicable diseases.

In relation to variables, family income $(\chi 2=0.422, \mathrm{df}=1)$, area of defecation $(\chi 2=2.664, d f=1)$, uses of foot wears $(\chi 2=0.791, d f=1)$, hand washing $(\chi 2=0.874, d f=1)$, sources of information ( $\chi 2=4.029, \mathrm{df}=2)$, history of communicable diseases $(\chi 2=0.405, d f=1)$ which does not show any association with level of knowledge.

Chi-square analysis to determine the association of attitude with selected demographic variables such age, sex, religion, type of family, education status, occupation.

The association of attitude with age $(\chi 2=0.415, d f=3)$, sex $(\chi 2=1.365, d f=1)$, religion $(\chi 2=0.536, d f=1)$, type of family $(\chi 2=0.208, d f=1)$, educational status $(\chi 2=1.974, d f=3)$, which does not show any association with level of attitude. In relation to variable occupation $(\chi 2=8.094, \mathrm{df}=3)$ which showed significant with $5 \%$ level at $P<0.05$.

Chi-square analysis to determine the association of attitude with selected demographic variables such as family income, area of defecation, uses of foot wears, hand washing, sources of information \& history of communicable diseases.

In relation to the variables, family income $(\chi 2=2.143$, $d f=1)$, uses of foot wears $(\chi 2=0.069, d f=1)$, hand washing $(\chi 2=0.533, d f=11)$, sources of information $(\chi 2=1.009, d f=2)$, history of communicable diseases $(\chi 2=3.733, \mathrm{df}=1)$ which does not show any association with level of attitude.

In relation to variable area of defecation $(\chi 2=4.138, \mathrm{df}=1)$ which showed significant with $5 \%$ level at $P<0.05$.

\section{Discussion}

The discussion is based on the objectives and hypothesis specified in this study. In order to achieve the objectives of the study a non experiment descriptive approach was used. Non probability Convenience sampling technique was used to select the samples. The study was conducted for about one month from 1st to 31th August 2011; the data was collected from 120 respondents through a structured interview schedule.

\section{Part I}

\section{Characteristics of the Demographic Variables}

The characteristics of the adults demographic variables described in terms of their frequency and percentage distribution which showed that, majority of adults 55 $(45.8 \%)$ were in the age group of $36-39$ years, $113(94.2 \%)$ was male, 112 (93.3\%) were Hindus, 96 (80\%) were belonging to joint family, $74(61.7 \%)$ of the subject had no formal education, 50 (41.7\%) were coolie/ labourer, 122 (93.3\%) of subject had family monthly income below $4000 /$ , $116(96.7 \%)$ of subjects used open field for defecation, $103(85.8 \%)$ of subjects wear foot wears while going for defecation, $60(50 \%)$ of subject washes their hand with water after defecation, 111 (92.5\%) got information from mass media, 105 (87.5\%) family does not have communicable disease. $^{3}$

The First Objective of the Study was to Assess the Existing Knowledge of Adults regarding the Importance of Sanitary Latrine

Out of 120 adults assessed regarding the importance of sanitary latrine $87(72.5 \%)$ were having moderately adequate knowledge, 28 (23.3\%) were found to have inadequate knowledge and $5(4.2 \%)$ of them had adequate knowledge regarding importance of sanitary latrine. The overall mean score for knowledge was 11.37 with a standard deviation of 2.64 and mean score percentage of 56.80 . The present study shows that the highest Mean score percentage $62.0 \%$ obtained for knowledge on Utilization of Govt. aid to construct sanitary latrine with Mean score of subject 3.10 with SD 1.08. The present study is supported by the findings of the following study. A descriptive study was conducted to assess the knowledge of the mother with defecation practices in relation to the prevalence, intensity and associated risk factors for infestation with Ascaris, hookworm and trichuris in tea growing communities of Assam. Single faecal sample were collected from 328 individual and was subjected to Kato-Katz quantisation technique. The overall prevalence of Ascaris was 38\%, hookworm and trichuris was $43 \%$. Results showed that, the children of mother with lack of knowledge, open field defecation practices were suffering with one or other helianthus infestations. ${ }^{4}$

The Second Objective was to Assess the Attitude of the Adults Regarding the Importance of Sanitary Latrine

The assessment of attitude of adults revealed that that $60(50.0 \%)$ adults were having moderately favourable attitude, 45 (37.5\%) were having unfavourable attitude and 15 (12.5\%) were having favourable attitude regarding importance of Sanitary latrine.

The mean and standard deviation of attitude of adults on importance of sanitary latrine are 34.03 and 8.77 respectively. The overall mean score percentage of attitude is 56.7. The present study is supported by the findings of the study. Two studies were conducted in a shantytown area of Lima, Peru. First, information was gathered through indepth interviews with mothers and structured observations (4 hours) of young children and their caretakers. Data on 
beliefs and practices related to faeces disposal behaviours were obtained. Excreta were deposited by humans in or near the house in $82 \%$ of households observed. While $22 \%$ of children aged 18 months were observed to use a potty for defecation, $48 \%$ defecated on the ground where the stools often remained. Hand nwashing after the child's defecation was extremely rare for both children (5\%) and caretakers (20\%). The hygienic disposal of faeces poses problems in this type of community. It was found that few people recognize that faeces transmit disease and faeces of young children were not felt to be as dirty or dangerous as those of adults or older children has been encountered. ${ }^{5}$

\section{Part II: Testing of Hypothesis}

\section{The Third Objective was to Correlate the Knowledge and Attitude of Adults regarding the Importance Sanitary Latrine}

The linear correlation between knowledge and attitude resulted to be positive, that is $r=0.478$ which was statistically significant at $P<0.01$ value. Hence the hypothesis $\mathrm{H} 1$ which stated "There is a significant correlation between the knowledge and attitude of rural people regarding sanitary latrine" was accepted.

The present study is supported by the findings of a sample survey conducted in rural homesteads in Swaziland related to latrine construction and used. Anthropological research techniques were also used to gain information on attitudes and beliefs. Pit latrines were found in $21 \%$ of the sampled homesteads. ${ }^{3}$

The most significant variables in predicting the presence of a latrine were respondent's education and the highest level of education achieved by anyone in the residential unit. Older people and small children were least likely to use a latrine; people with less education were least likely to even have a latrine.

\section{The Fourth Objective was to Associate the Knowledge and Attitude of Adults with Selected Demographic Variables}

The association test results revealed that there is no statistically significant association between knowledge of adults with the demographic variables. But there is statistically significant association between attitude of adults with the demographic variables occupation and area of defecation. Hence the hypothesis $\mathrm{H} 2$ which was stated "There is a significant association between knowledge, and attitude of the adults with selected demographic variables" was accepted. The present study is supported by the findings of a case study was conducted in Infectious Diseases Hospital, Delhi 1992, in which Rectal swabs from 2783 cases were bacteriologic ally examined, out of which 1075 were found to be positive for Vitriol cholera. Detailed epidemiological information was collected for about 198 cases of diarrhoea out of which 103 were confirmed cases of cholera. Half of these cases occurred in children below 10 years of age. And it was found that cases occurred in those who were illiterate or educated up to primary level. Among the important risk factors were absence of sanitary latrines and habit of washing hands with water alone after defecation, before cooking and eating food. The findings suggest that the hygienic practices were important contaminant for transmission of cholera. ${ }^{2}$

\section{Conclusion}

In a developing country like India, where $80 \%$ of the population lives in rural area, there are many constraints for better living. And the practice of open field defecation is still the main problem leading to communicable diseases. However, the risk from communicable diseases can be prevented if sanitary latrine is constructed and used.

\section{Based on Findings Obtained the following Conclusions} were made

The findings of the study have been discussed with reference to the objectives, hypothesis and with the findings of other studies. The data is organized, analyzed and presented. The findings of the shows that majority of the adults 87 (72.5\%) had moderate adequate knowledge, 60 (50\%) of adults had moderately favourable attitude. This showed that knowledge and attitude of the adults are inadequate and health educations regarding importance of sanitary latrine are needed to improve the knowledge and attitude.

Therefore, the investigator has provided health education pamphlet importance of sanitary latrine to the subjects which will help them to upgrade and reinforce their knowledge regarding importance of sanitary latrine.

\section{Conflict of Interest: None}

\section{References}

1. Latrine. Available from: https://en.wikipedia.org/wiki/ Latrine.

2. Choudhury N, Mohammad AH. Exploring the current status of sanitary latrine use in Shibpur Upazila, Narsingdi District. BRACReport, 2006. Available from: https://research.brac.net/new/books/sanitarylatrine. [Google Scholar].

3. Billalli SF, Nagaraja BG, Prasanna Kumar DR. A study to assess the knowledge of adults regarding importance of sanitary latrines in Basha Nagar Davangere with a view to Develop Pamphlet. International Journal of Advances in Nursing Management 2017; 5(3): 211214. Available from: http://ijanm.com/AbstractView. aspx?PID=2017-5-3-4 [Google Scholar].

4. Anuradha R, Dutta R, Raja JD et al. Role of community in Swachh Bharat Mission their knowledge, attitude 
and practices of sanitary latrine usage in rural areas, Tamil Nadu. Indian J Community Med 2017; 42(2): 107110. Available from: http://www.ijcm.org.in/article. asp issn=0970-0218; year $=2017$; volume $=42 ;$ issue $=2$ ;spage=107; epage=110; aulast=Anuradha [PubMed/ Google Scholar].

5. Introduction to Sanitation and Waste Management. 2019. Available from: https://www.open.edu/openl earncreate/mod/oucontent/view.php?id=80395 \&printable=1. 